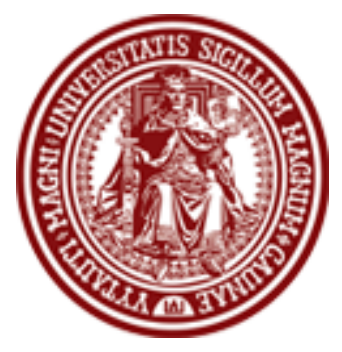

BALTIC JOURNAL OF LAW \& POLITICS

VOLUME 6, NUMBER 1 (2013)

ISSN 2029-0454

http://www.degruyter.com/view/j/bjlp

Cit.: Baltic Journal of Law \& Politics 6:1 (2013): 106-139

DOI: $10.2478 / \mathrm{bjlp}-2013-0006$

\title{
ENERGY SECURITY CHALLENGES, CONCEPTS AND THE CONTROVERSY OF ENERGY NATIONALISM IN LITHUANIAN ENERGY POLITICS
}

\author{
Giedrius Česnakas \\ Doctoral Candidate \\ Faculty of Political Sciences and Diplomacy, Vytautas Magnus University \\ (Lithuania) \\ Contact information \\ Address: Gedimino str. 44, LT-44248 Kaunas, Lithuania \\ Phone: +370 37206704 \\ E-mail address: g.cesnakas@pmdf.vdu.It
}

Received: June 12, 2013; reviews: 2; accepted: July 25, 2013.

\section{ABSTRACT}

The article analyses how responsible decision makers (Members of the Parliament and employees in the Governmental institutions) adopt their decisions on the issues concerning energy security of Lithuania. The article is based on a constructivist security approach. The article explores what the main challenges and threats to Lithuanian energy security are, as identified by responsible decision makers. The article analyses how the concept of "energy security" is perceived by responsible decision makers. Additionally, the article identifies the groups that most influence the positions of the responsible decision makers. Finally, it is stated that energy nationalism dominates the thinking of responsible decision makers, which is perceived as a way to increase energy security.

\section{KEYWORDS}

Energy security, energy nationalism, decision makers, nuclear plant, Lithuania, Russia 


\section{NOTE}

This research was funded by a grant (No. MIP-010/2011) from the Research Council of Lithuania. 


\section{INTRODUCTION}

After closure of the second block of the Ignalina nuclear power plant (NPP), Lithuania imports $79 \%$ of its total energy consumption. ${ }^{1}$ The Russian Federation is the single supplier of oil and natural gas, while Lithuania imports $60 \%$ of gross consumed electricity, most of it from Russia as well, and through its dominated BRELL grid. ${ }^{2}$ Lithuanian political and public discourse is dominated by energy security issues as well as discussions on projects that should increase energy security. The Lithuanian government is planning at least three major energy projects: construction of Visaginas NPP, construction of liquefied natural gas (LNG) terminal in Klaipeda port, and electricity grid connections (Power Bridges) with Sweden and Poland. The Lithuanian government also strives to increase production of local and renewable energy resources. A natural gas pipeline between Lithuania and Poland is also being discussed. But for the time being, Lithuania is very vulnerable to the energy policies of Russia as well as reliability of prices and supply.

These energy projects are outcomes of Lithuanian energy security policy which is constructed on the basis of the quantitative data (consumption, production, import, transit, diversification, etc.), as well as perceptions of challenges, concepts of security and ways those subjective perceptions and interpretations are being constructed. In contrast to the liberal or realistic approach(s), underlining the rationality in decision making, ${ }^{3}$ it must be stressed that responsible decision makers are individuals who not only use objectivequantitative data, but also interpret it through their political agenda and personal experience as well as being influenced by different interest groups and discourses. Subjective perceptions play an even greater role because quantitative data needs inevitable interpretation that might be very different in most cases from what energy security, threats, as well as ways to increase energy security are. The same data could be differently interpreted by various political parties - conservatives, social democrats, liberals, allowing them to interpret data to validate their statements and views. This way quantitative data and subjective interpretations' elements influence their votes and decisions, which become decisions of the state.

\footnotetext{
${ }^{1}$ Lietuvos statistikos departamentas [Lithuanian Department of Statistics], "2010 m. Keitèsi šalies ir energijos sąnaudu struktūra" ["Changed National Fuel and Energy Structure in 2010"], (June 15, 2011) // http://www.stat.gov.It/lt/news/view/?id=9044 (accessed May 4, 2012).

2 Statistics Lithuania, "Energy Balance 2010," Vilnius (2011): 38 //

http://web.stat.gov.It/It/catalog/pages_list/?id=1566 (accessed May 4, 2012). Lithuania is connected into Belarus, Russian, Estonian, Latvian, and Lithuanian - BRELL electricity grind synchronized within BRELL and not with continental European grinds.

3 Gal Luft \& Anne Korin, "Realism and Idealism in the Energy Security Debate": 335-349; in: Gal Luft and Anne Korin, eds., Energy Security Challenges in the $21^{\text {st }}$ Century. A Reference Handbook (United States of America: ABC-CLIO, 2009).
} 
The energy security policies as well as all other policies are formed by actors responsible decisions makers. The international energy system, the state of domestic energy system, political, economical and social elements creates patterns for the decisions of the responsible decision makers.

Up until now in the field of political sciences and international relations, energy security is dominated by historical descriptive approach through interpretation of various events, or analysis of energy projects and their possible impact on energy security. ${ }^{4}$ However, there is a lack of research that would allow understanding what elements of energy are perceived as challenges to energy security, how energy security is perceived and defined, and finally, how energy security perception of the responsible decision makers, such as members of the parliament (Lt. Seimas), members of the governmental (Lt. Vyriausybè) institutions, are constructed. Members of parliament and government form and implement national energy security policy and their decisions concerning this issue are regarded as official positions of Lithuania, so they are the most influential elements of the society influencing the perceptions of citizens.

This article is based on empirical research that indicates how energy security is perceived by responsible decision makers in Lithuania. In order to understand this perception, the article is divided into five empirical research objectives. The first objective is what kind of challenges responsible decision makers see for Lithuanian energy security. The second objective is to understand how they define concept of energy security. The third objective is to indicate how they assess energy security. The fourth step is to identify what specific groups influence responsible decision makers and if as well as how they are influenced by information in mass media and public discourse. Finally, the case analysis of how NPP projects in Lithuania, Belarus and Russia (Kaliningrad) are assessed, which helps determine whether energy nationalism, which is one of the most important energy security issues presented in the National Energy Strategy and the National Energy Independence Strategy in case of Russia, can also be found in the perceptions of the responsible decision makers in Lithuania.

The research is based on semi-structured interviews with Parliament members of the Republic of Lithuania and employees of the Government of the Republic of Lithuania (not lower ranking than the head of division). The interviews were

\footnotetext{
4 Tomas Janeliūnas and Arūnas Molis, "Energy Security in Lithuania: Challanges and Perspectives," Lithuanian Political Science Yearbook 2005 (2006): 200-233; Gediminas Vitkus, "Russian Pipeline Diplomacy: A Lithuanian Response," Acta Slavica Iaponica 26 (2009): 25-46; Kęstutis Budrys, "Bendradarbiavimo su Lenkija itaka Lietuvos energetiniam saugumu" ["Impact of the Cooperation with Poland on Lithuanian Energy Security"], Lietuvos metinè strateginé apžvalga 2007 (2008): 213-240; Tomas Janeliūnas, "Lithuanian energy strategy and its implications on regional cooperation": 190-222; in: Andris Sprūds and Toms Rostoks, eds., Energy: Pulling the Baltic Sea Region together or apart (Riga: Zinatne, 2009).
} 
analyzed, and documents too that finally synthesize all these methods and presented findings. The first part of the article analyzes constructivist approach in the research of energy security, focusing on the Copenhagen School. The second part is the empirical part that presents findings from the interviews with responsible decision makers, using tables of elements, and positions of the interviewees. Finally, the article ends with conclusions presenting the main insights.

\section{CONSTRUCTIVISM IN ENERGY SECURITY STUDIES}

Certain objects and events are not elements of security or threats per se, because assumptions about objects and events as threats or elements of security are constructed through meanings that are given to them. In the studies of energy security, as well as other fields of security, energy resources and elements related to them are securitized not necessarily on the basis of quantitative data, but on perceptions and estimations. Assumptions about security and threats to security depend on political context.

The analytical base of security studies is the Copenhagen School. The Copenhagen School, developed by Barry Buzan and Ole Waever, can hardly be assessed as theory, but rather as an analytical framework regarded as the emancipation of security studies through a constructive approach. In this school there are three major pillars or ideas: securitization, sectors, and regional security complexes. The concept of securitization is most broadly defined on metatheoretical base of Copenhagen School. ${ }^{5}$ Security is defined as freedom from threat and the ability of states and societies to maintain their independent identity and their functional integrity against forces of change, which they see as hostile. ${ }^{6}$

Though there are three levels of security: individual, state and national security, the security concept is directly connected with the state and security has to be read through the lens of national security. ${ }^{7}$ According to Waever, security problems are developments that threaten sovereignty or independence of the state in a particular rapid or dramatic fashion leading to undercut of political order, while

\footnotetext{
${ }^{5}$ Ole Waever, "New Schools' in Energy Security Theory and their Origins between Core and Periphery," Paper presented at the annual meeting of the International Studies Association, Montreal (March 17-20, 2004): $7 / /$

http://www.google.It/url?sa=t\&rct=j\&q=new\%20schools\%E2\%80\%99\%20in\%20energy\%20security\%2 0theory\%20and\%20their\%20origins\%20between $\% 20$ core $\% 20$ and\%20periphery\&source =web\&cd $=1 \& c a$ $\mathrm{d}=$ rja\&ved =0CCoQFjAA\&url=http $\% 3 \mathrm{~A} \% 2 \mathrm{~F} \% 2 \mathrm{Fconstructivismointegracion.wikispaces.com} \% 2 \mathrm{Ffile} \% 2 \mathrm{Fvie}$ w\%2FAberystwyth\%2C\%2BParis\%2C\%2BCopenhagen\%2BNew\%2B'Schools'\%2Bin\%2BSecurity.doc\&ei $=y C \_M U b 3 m N c z 3 s g a P 3 Y H A A g \& u s g=A F Q j C N E j D V A r s 3 \times 1 A x K p H 85 j 9 N 4 T Q S d n x Q$ (accessed May 4, 2012).

6 Barry Buzan, Žmonès, valstybès ir baime: tarptautinio saugumo studijos po Šaltojo karo [People, States and Fear: An Agenda for International Security studies in the Post Cold War Era], trans., ed. Gediminas Vitkus (Eugrimas, 1997), p. 51.

7 Ole Waever, "Securitization and Desecuritization": 48; Ronnie D. Lipschutz, ed., On Security (Columbia University Press, 1995).
} 
deprive of the capacity to manage by itself. ${ }^{8}$ Nevertheless it is argued that "security" is not considered to be a direct consequence of threat, but is defined by political interpretation of that threat. ${ }^{9}$ The problems and issues had to be securitized, while the process of "securitization" is described as a discursive construction of a particular issue as security threat. ${ }^{10}$ According to Waever, the task of securitization is not to assess objective "real" threats endangering some objects, but rather to construct a shared understanding of what it is to be considered a threat and collectively respond. The process of securitization is considered a speech act ${ }^{11}$ while hawing means to resist the threat ${ }^{12}$ and only political elite of the state responsible decision makers, can name an object or process a security issue - and thus securitize it ${ }^{13}$. The securitization expands state (governmental) power because it takes the issue beyond the established rules of the game, putting it above the normal politics ${ }^{14}$ and political institutions can claim their special powers, monopolizing the elements, resources and means needed for de-securitization ${ }^{15}$. It can also be assumed that the institutions might strive to keep expanded power and not to de-securitize the issue even if vulnerability was lowered to "acceptable level", accentuating concept of widening security and "spill" of the issue into other areas. The process of de-securitization is understood as moving issues back to normal politics not necessary creating countermeasures to the threats. ${ }^{16}$ This means that an issue can be regarded as a threat to security, but without creating measures only by changed perception, or even without that, the issue might become no longer regarded a threat, or different responsible decision makers can differently perceive the issue and de-securitize it. For this case "security" and "insecurity" are not objective categories, because political elite in the institutions define security and securitize issues. ${ }^{17}$ When, after elections or in other cases, new political parties and individuals come to power and form government, they can define security in other manner and de-securitize the issue. Volatility on security and de-securitization is not as high as it could be because even individual responsible decision makers could have very different views on security issues and securitize different objects and processes, the structure of the democratic state determines that different actors must agree on the common denominator. This

\footnotetext{
${ }^{8}$ Ibid.: 51.

9 Andrei Belyi, "New Dimensions of Energy Security of the Enlarging EU and their Impact on Relations with Russia," European Integration Vol. 25(4) (December 2003): 354.

10 Matt McDonald, "Securitization and the Construction of Security," European Journal of International Relations Vol. 14(4) (2008): 563.

${ }^{11}$ Ole Waever, supra note 5: 8.

12 Ole Waever, supra note 7: 54.

13 ibid., p.51

${ }^{14}$ Ole Waever, supra note 5: 8.

15 Ole Waever, supra note 7: 51.

16 Ole Waever, supra note 5: 9.

17 Ole Waever, supra note 7: 53.
} 
common denominator is at a different distance from the ideal case of each responsible decision maker, while it is closer to the decision makers' positions that have the majority in the parliament and forms the government, and further from the ideal cases of members of the oppositional parties.

Energy security is not distinguished as a separate security sector in the Copenhagen school. Energy security is a part of the economic security sector, but energy security clearly affects distinguished security sectors like: political, military, societal, economical and environmental. ${ }^{18}$ Increasing concerns of energy security in practical individual, state and international security, as well as increasing research in this area allows arguing that energy security can be regarded as a separate security sector.

\section{METHODOLOGY OF THE RESEARCH}

The qualitative research methodology here focuses on the semi-structured interviews with responsible decision makers: Parliament Members and employees of the institutions of the Government of the Republic of Lithuania. Close cooperation between Parliament and the Government is needed in the legislative process. The Government prepares and proposes laws that have to be adopted by the Parliament with proposed corrections or amendments, or without them. Laws can also be initiated by the Parliament and the President. Finally, the laws come into force when they are signed by the President and officially published.

Parliament and Government dominate the legislation process, so the focus was on the members of these institutions. A number of Parliament Members from the majority as well as oppositional fractions were selected. Inquiries for interviews were sent to the Parliament Members from three political groups of the majority, and to the members of two political groups in the opposition. It was important that interviewees would be members of at least one of the Committees on Environmental Protection, National Security and Defense, Foreign Affairs, or a member of the Nuclear Energy Commission. Members of Committee on National Security, to whom letters for interviews were sent, rejected any interviews, while members of other committees and commission agreed to give interviews. There were five interviews conducted with the Parliament Members who are members of three political groups: the Homeland Union - Lithuanian Christian Democrat Political Group $^{19}$ (in total 46 members) - interviews were taken from three members; the Lithuanian Social Democratic Party Political Group (in total 23 members) -

\footnotetext{
${ }^{18}$ Barry Buzan, supra note 6, p. 169 - 178; Andrei Belyi, supra note 9: 354.

19 Homeland Union - Lithuanian Christian Democrat Political party is the biggest conservative party in Lithuania.
} 
interview was taken from one member; the Order and Justice Political Group (in total 17 members $)^{20}$ - an interview was taken from one member. Three interviewees were members of the Nuclear Energy Commission, three were members of the Committee on Foreign Affairs, and one was a member of the Committee on Environmental Protection.

Three interviews were conducted with the interviewees who work in the ministries or institutions that are directly accountable to the ministries and ranking not lower than head of division. Interviewees were from: the Ministry of Energy, the Ministry of Foreign Affairs, and the Energy Security Centre under the Ministry of Foreign Affairs. Members of these institutions agreed to give direct interviews except one member of the Ministry of Foreign Affairs, who only agreed to answer the questions in written form.

All the interviews were taken in the period between 2 April 2012 and 27 April 2012. It was agreed that the names of the interviewees will not be disclosed. The following questions were prepared:

- What are the main challenges for Lithuania's energy security?

- How would you define the concept of "energy security"? Does energy security have connections with the concept of "energy independence"?

- How would you evaluate the level of Lithuania's energy security on a scale ranging from 1 to 10 , where 1 is the most insecure you can imagine, and 10 is greatest security as you can imagine?

- Do you know energy security evaluation methods created by experts scientists (scientists in the field of energy, political scientists, economists and environmentalists)? Do you use these methods and data?

- Who do you consult with while analyzing Lithuania's energy (in)security, and what groups (scientists in the field of energy, political scientists, economists and environmental scientists, NGO's, business groups)? How do they affect your assessments on energy security?

- Is your position on energy security influenced by information in mass media and public opinions?

- Please comment on how these projects will affect Lithuanian energy (in)security.

- How will Lithuanian energy security be affected by the selection of the strategic investor to the Visaginas NPP and signing of the initial treaty?

- How will Lithuanian energy security be affected by NPP projects in Belarus and Russia (Kaliningrad region)?

20 There are 141 members in the Parliament of the Republic of Lithuania. This was a new variant the strategy presented for the parliament in 2010 and in withdrawn by the government for corrections in 2011. 
- How will Lithuanian energy security be affected by the commissioning of the Nord Stream pipeline?

These questions were sent to the interviewees in advance. During the interviews some additional questions were given in order to increase accuracy and avoid misperceptions. Interviewees were allowed to answer the question as long as they wanted and only then additional questions were given. All the interviews took at least 45 minutes and the longest ran up to 1 hour and 10 minutes.

Interviews were conducted in Lithuanian, recorded and then transcribed. The transcribed interviews were analyzed and interpreted in order to answer the aims and goals of this research. Analysis of the main documents concerning energy security policy of Lithuania was also done. National Energy Strategy adopted on 18 January 2007 and National Energy Independency Strategy presented to the Parliament on 10 May 2012 were analyzed. ${ }^{21}$ The comparison of the answers of the interviewees and the documents was done in order to identify whether official documents influence and form positions of the interviewees. If the answers of the interviewees have the same core elements presented in the documents then it can be assumed that interviewees know these documents and their decisions are based on them.

\section{CHALLENGES AND THREATS TO ENERGY SECURITY}

Seeing that energy security is perceived as freedom from threats, that is primarily based on the assessments of the responsible decision makers on what challenges or threats to the normal stance of energy and national security sector exist. Identification of threats for the most part defines energy security. Interviewees had to name the main challenges for the energy security of Lithuania.

Challenges and threats for energy and national security arising from energy issues are presented in the National Energy Strategy (prepared by the Government of Lithuanian Social Democratic party and coalition) and National Energy Independency Strategy (prepared by Homeland Union - Lithuanian Christian Democrat Political party in coalition with liberals). It was expected that there would be a high correlation between challenges and threats presented in strategies and the responses of interviewees.

The National Energy Strategy directly connects challenges to energy security with challenges to national security in the articles 6, 7 and 8 . In the document, challenges to energy and national security are divided into three spheres: challenges related to the global processes, challenges related to the regional

21 On 26 June 2012 the National Energy Independence Strategy was adopted by the Lithuanian Parliament. 
processes (concerning the EU) and challenges directly affecting Lithuania. Challenges related to the global processes are divided into eight types: depletion of the global energy resources and growing demand exceeding rate of reconnaissance, use and development of new fields; a considerable amount of oil and gas resources are located in and politically unstable and nondemocratic countries expanding political control of resources; complicated relations of Western democracies with the countries rich in energy resources; substantially increased geopolitical role of energy resources exporting states allowing them to dictate terms to the importing countries; an increased political activity of governments in energy markets; the grown influence of the energy as a lever to shape countries' foreign and national security policies; the growing political restrictions on the freedom of the market; increasing interaction of the main economies in energy markets and their interaction with Russia. This document was adopted half a year after the disruption of the Druzhba - 2 oil pipeline to Lithuania after oil refinery in Lithuania was sold to Polish company PKN Orlen and not Russian company, after Russian - Ukrainian gas conflict, and ongoing Russian - Belarusian gas conflict. Of course the story of Yukos was perceived as expansion of Russian state power in the energy sector. The document reflects that Russia is the main determinant of energy (in)security challenges at the global level.

Challenges at the regional, or the EU level, reflect challenges defined in the European Commission Green Paper - A European Strategy for Sustainable, Competitive and Secure Energy, as well as claiming that challenge is the absence of the EU common energy policy, lack of supply alternatives, and lack of interconnections between regions. ${ }^{22}$

Challenges directly affecting Lithuania are presented in the article eight of the National Energy Strategy:

prevalence of import of primary energy resources from Russia, dependence of Lithuania's gas supply and electricity systems on Russia's energy systems as well as absence of interconnections with Western European energy systems; the decommissioning of the Ignalina NPP in 2009, which has a considerable detrimental effect on the structure of electricity sources, primary energy balance and electricity price in 2010-2015;

the construction of a new gas pipeline to Europe under the Baltic Sea bypassing the territory of the Baltic States;

22 Commission of the European Communities, "Green Paper: A European Strategy for Sustainable, Competitive and Secure Energy," (Brussels, 8.3.2006 COM (2006) 105 final): 4-5 //

http://europa.eu/documents/comm/green_papers/pdf/com2006_105_en.pdf (accessed: May 7, 2012). 
the strict environmental requirements set forth to energy enterprises, including restrictions on carbon dioxide (hereinafter referred to as " $\mathrm{CO}_{2}$ ") emissions. ${ }^{23}$

Russia or elements directly related to it remain the main determinants influencing Lithuanian energy security, except for the last environmental challenge. The only existing gas and electricity interconnections with Russia and not the EU countries indicate the vulnerability of supply, while greater import of electricity from Russia increases vulnerability of supply and price, while the Nord Stream pipeline is also perceived as a challenge.

In the National Energy Independence Strategy it is claimed that Lithuania faces challenges in three fields: security of supply, competitiveness and sustainable development. The Strategy mainly focuses on the domestic challenges to energy security, while only briefly mentions the EU context, and does not present challenges at the global level to Lithuanian energy security. Challenges to energy in the Strategy security are: increased dependence on imported electricity and fossil fuel after closure of the Ignalina NPP; isolation from EU energy systems and dependence on single supplier; lack of competition in Lithuanian energy sector; energy inefficiency; high production of $\mathrm{CO}_{2}$. The whole strategy is prepared in a way to show that non-implementation of in the strategy proposed energy projects (Visaginas NPP, interconnections with Sweden and Poland, implementation of the EU Third Energy Package, creation of regional energy market and integration of it into the Northern and continental Europe energy markets, synchronization with ENTSO-E, LNG project, expansion of production and use of renewable resources, gas pipeline to Poland) are the main challenges to energy and national security. At the same time in the document it is noted that non-implementation of projects (keeping status quo) creates negative consequences that are as follows:

- Dependence on the single supplier and energy monopolies of the foreign states leading to the prices that are based not on the market principles;

- $\quad$ Energy resources might be used as tools for geopolitical aims;

- Low competitiveness and vulnerability of supply;

- $\quad$ Electricity imported from non EU member states and from not safe nuclear power plants;

- Country remains in the influence of Eastern geopolitical space;

- Domestic market is not liberalized and alternative suppliers have no access to supply networks which leads to the lack of competition and non-favorable prices for consumers;

- Dependence on fossil fuel and growing prices would decrease competitiveness of the economy;

\footnotetext{
${ }^{23}$ National Energy Strategy, Official Gazette (2007, no. 11-430), Art. 8.
} 
- Potential of renewable and domestic resources would not be used and low efficiency would lead to increased import of electricity and energy dependency. ${ }^{24}$

In the National Energy Independence Strategy all challenges and threats are directly related to the main importer of energy resources - Russia, and dependence on Russia. It was expected that Russia will be named as the main challenge or threat to Lithuanian energy security, but the information of the interviews shows that Russia is the key issue in Lithuanian energy security. In some interviews Russia was not perceived as a threat to the energy security of Lithuania, but nevertheless it was accentuated as the major determinant of threats.

Nearly all the interviewees claimed that the main challenge to energy security is dependence on a single supplier - Russia. Only one interviewee did not claim that it is challenge to energy security, and this interviewee even argued that dependence on Russia is source of security. The second most mentioned challenge was lack of market principles in the energy sector, but only 3 of 8 interviewees in one form or another mentioned this challenge. Three challenges were mentioned by two interviewees: high prices of energy resources, low energy efficiency and lack of interconnections with EU member states. Other challenges were mentioned only by individual interviewees. The challenge most mentioned relates to core challenges presented in the strategies. It was surprising that interviewees did not have similar positions on other challenges; for instance, energy intensity issues and environmental challenges were not even mentioned, though they are presented in both strategies.

The positions of most interviewees towards Russia as main challenge to Lithuania's energy security were harsh. Interviewee No. 1 argued that the main challenge is dependence on imported energy resources and "new nuclear power plant in which imported nuclear fuel will be used"; he also claimed that "we [Lithuania] feed energy exporters with our money and at the same time we are dependent on them". Interviewee No. 2 argued that the main challenge is "our [Lithuanian] energy dependencies - the lack of our freedom to choose the energy providers", he also raised the rhetorical question: "which fool could believe that we gained independence after Russia had withdrawn its military and recognized independence de jure?" Interviewee No. 3 argued that for the whole period since 1990 Lithuanian governments had the position that "we need independence, but for now Russian oil and Russian gas is 2,3,4,5 cents cheaper". Interviewee No. 5 was not able to identify challenges, and only argued that "question of energy independence is the most important". Interviewee No. 6 was able to clearly identify

\footnotetext{
${ }^{24}$ National Energy Independence Strategy, Official Gazette (2012, no.80-4149), Art. 36.
} 
challenges for energy security. Interviewee No. 7 argued "when you ask [for energy resources], they give you, so it is fine, but decision always depends on the supplier". The most original insights on challenges to energy security were presented by interviewee No. 4. He argued that challenges to energy security originate from "geopolitical blindness"25, politicized and ideological decisions of the right wing parties, Russophobes, and incapability to implement energy projects". While all other interviewees more or less positively assessed currently developing energy projects, one interviewee named them as challenges or event threats to Lithuanian energy, social and national security, except for renewable energy development projects.

Table 1. Categorized challenges to Lithuanian energy security

\begin{tabular}{|c|c|c|c|c|c|c|c|c|c|}
\hline Challenges & 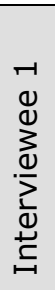 & 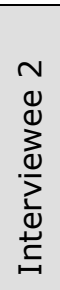 & 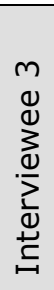 & 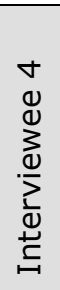 & 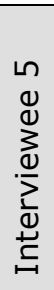 & 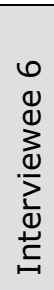 & 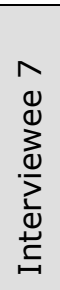 & 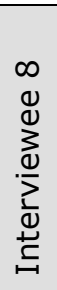 & 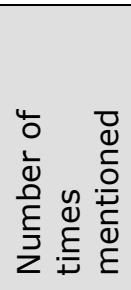 \\
\hline $\begin{array}{l}\text { Dependence on import from } \\
\text { single supplier (Russia) }\end{array}$ & + & + & + & & + & + & + & + & 7 \\
\hline $\begin{array}{l}\text { Lack of market principles in } \\
\text { trade of energy resources }\end{array}$ & & & & & & + & + & + & 3 \\
\hline $\begin{array}{l}\text { High price of energy } \\
\text { resources }\end{array}$ & & + & & & & & + & & 2 \\
\hline Low energy efficiency & + & & & + & & & & & 2 \\
\hline $\begin{array}{l}\text { Lack of energy } \\
\text { interconnections with Europe }\end{array}$ & & & & & & + & + & & 2 \\
\hline $\begin{array}{l}\text { Political stereotypes about } \\
\text { Russia ("geopolitical } \\
\text { blindness") }\end{array}$ & & & & + & & & & & 1 \\
\hline $\begin{array}{l}\text { Wrong policy of the } \\
\text { governments while developing } \\
\text { projects }\end{array}$ & & & & + & & & & & 1 \\
\hline $\begin{array}{l}\text { Perception that Russia will } \\
\text { supply energy resources for } \\
\text { lower price }\end{array}$ & & & + & & & & & & 1 \\
\hline Energy independence strategy & & & & + & & & & & 1 \\
\hline
\end{tabular}

To sum up: only one interviewee named absolutely unique challenges, even opposing challenges presented in both energy strategies. The research showed that this radical position is not broadly shared, because most of the interviewees shared similar perceptions about the challenges to Lithuanian energy security, that were in line with the main challenges presented in the Strategies.

While identifying what negative consequences of the challenges Lithuania might have, respondents mainly focused on two aspects: insecurity of supply for

25 Interviewee perceived "geopolitical blindness" as assessment that Russia is a threat, and because of that Russian companies should not be allowed in Lithuanian energy sector or projects. 
technical reasons; and, insecurity of supply for political reasons. These aspects were mentioned by five interviewees and resemble negative effects presented in the National Energy Independence Strategy concerning vulnerability of supply because of technical and geopolitical reasons. The securitization of energy supplies from Russia was very clearly expressed by Interviewee No. 2, who argued that "to say it sound, today the wars are not fought with tanks and infantry in these latitudes, they are fought by means of energy and propaganda, and we [Lithuania] are in the middle of the battle". This position shows how extremely securitized the perception of Russia and energy by the responsible decision makers is. On the other hand, Interviewee No. 1 claimed that during his meeting with the members of the Russian Duma he inquired why pipeline Druzhba-2 had broken down, on member of Duma stated that "it was necessary", and pipeline will be fixed "then when it's needed". This shows that the securitization is not based only on misguided perceptions about Russia. Interviewee No. 4 called these kinds of perceptions "geopolitical blindness" and paranoia.

It was surprising that the interviewees named a wide spectrum of possible negative consequences, but they never coincided except for the already mentioned vulnerability of supply for technical of political reasons, and what can be aggregated as category of higher energy resources prices and lack of energy market (mentioned for three times).

Table 2. Categorized negative effects of the challenges to the energy security presented by interviewees

\begin{tabular}{|c|c|c|c|c|c|c|c|c|c|}
\hline $\begin{array}{l}\text { Negative effects of } \\
\text { challenges to energy } \\
\text { security. }\end{array}$ & 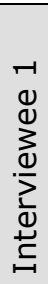 & 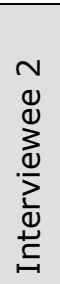 & 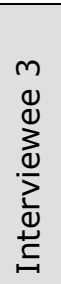 & 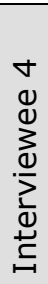 & 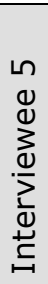 & 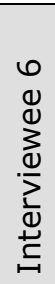 & 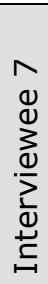 & 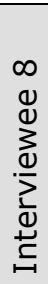 & 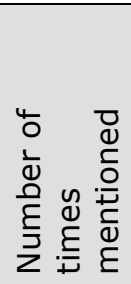 \\
\hline $\begin{array}{l}\text { Insecurity of supply for } \\
\text { technical reasons }\end{array}$ & + & & & & + & + & + & + & 5 \\
\hline $\begin{array}{l}\text { Insecurity of supply for } \\
\text { political reasons }\end{array}$ & + & + & & & & + & + & + & 5 \\
\hline $\begin{array}{l}\text { Higher price of resources } \\
\text { and lack of energy market }\end{array}$ & & & & & + & + & + & & 3 \\
\hline $\begin{array}{l}\text { Insecurity of supply for } \\
\text { economical reasons } \\
\text { (monopoly) }\end{array}$ & & & & & & & & + & 1 \\
\hline Threat to national security & & + & & & & & & & 1 \\
\hline $\begin{array}{l}\text { Country will remain in } \\
\text { sphere of Russian influence }\end{array}$ & & & + & & & & & & 1 \\
\hline $\begin{array}{l}\text { Non developed alternative } \\
\text { energy projects with } \\
\text { Russian investments }\end{array}$ & & & & + & & & & & 1 \\
\hline
\end{tabular}




\begin{tabular}{|l|l|l|l|l|l|l|l|l|l|}
\hline $\begin{array}{l}\text { Construction of Visaginas } \\
\text { nuclear power plant }\end{array}$ & & & & + & & & & & 1 \\
\hline $\begin{array}{l}\text { Construction of nuclear } \\
\text { power plants in Russia } \\
\text { (Kaliningrad) and Belarus }\end{array}$ & & & & + & & & & & 1 \\
\hline Impact of global processes & & & & & & + & & & 1 \\
\hline $\begin{array}{l}\text { Negative affect to other } \\
\text { security sectors }\end{array}$ & & & & & & & + & & 1 \\
\hline
\end{tabular}

The identified challenges as well as negative consequences of the challenges influence how "energy security" is defined. As it will be observed later, diversification will dominate the definitions of the concept of "energy security". Inconsistencies are observed as well, because price of energy resources was much more accentuated than market principles. However, market principles could be perceived as element of diversification. Also, environmental principles while defining energy security were more accentuated than it could be predicted from information received from previous answers, because only two respondents mentioned energy efficiency issue which is directly connected to environmental issues. Only a single interviewee mentioned that plans to construct NPPs' in Belarus and Kaliningrad have no negative effects from the challenges in energy sector, but during the interviews negative perception about these projects was presented by most interviewees.

\section{PROBLEMS DEFINING ENERGY SECURITY}

The National Energy Strategy does not present a definition of energy security, though article 5 states that energy security is based on the number of provisions and third and fourth provisions state that:

Energy security covers the totality of the conditions ensuring the diversity of traditional and renewable primary sources of energy, diversity and security of energy supply and independence from dictate of a monopolistic supplier, availability of energy to the consumer at acceptable prices in a competitive energy market;

Lithuania links its energy security to the integration of the country's energy systems into EU energy systems and with an efficient EU and national energy policy, which should ensure that Lithuania's energy security would be on a par with that of other EU states. ${ }^{26}$

The National Energy Independency Strategy states that the main aim is to "achieve energy independence by the year 2020, this would strengthen energy

\footnotetext{
${ }^{26}$ National Energy Strategy, supra note 23, Art. 5, Sec. 3-4.
} 
security and competitive abilities". ${ }^{27}$ At the same time in the document it is claimed that "energy independence" means "Energy needs of Lithuania will be satisfied using domestic energy resources as well as their diversified supply". ${ }^{28}$ In another part of the document "energy independence" is defined as "the ability to choose freely the type of energy resources as well as suppliers (including domestic production) that best responds to energy security demands of the state and the interests of Lithuanian consumers, to buy energy resources at most favorable price". ${ }^{29}$ The concept of "energy independence" consists of different elements in the text of the Strategy. For example, in the document it is argued that if Lithuania achieves "energy independence" it will become a part of the completely different geopolitical and value space, which is based on market relations and competition, equal conditions and transparency between members of energy market. ${ }^{30}$ Overall the Strategy lacks consistency.

Interviewees were asked to define energy security and whether it has connections with concept of "energy independence".

Table 3. Categorized elements of "energy security" concept

\begin{tabular}{|c|c|c|c|c|c|c|c|c|c|}
\hline $\begin{array}{l}\text { How would you define concept } \\
\text { of "energy security"? }\end{array}$ & 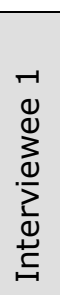 & 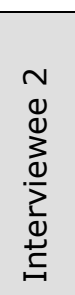 & 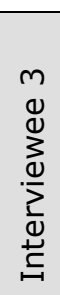 & 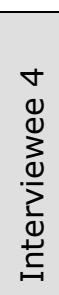 & 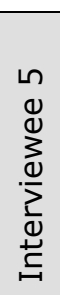 & 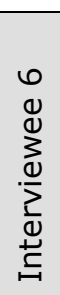 & 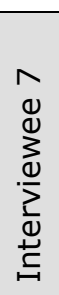 & 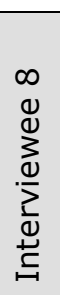 & 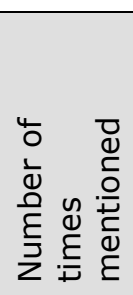 \\
\hline $\begin{array}{l}\text { Diversified geographic energy } \\
\text { supply }\end{array}$ & + & + & + & + & + & + & + & + & 8 \\
\hline Diversified energy resources & & + & + & & & & + & + & 4 \\
\hline Self sufficiency & + & + & & & + & & & & 3 \\
\hline $\begin{array}{l}\text { Acceptable price for energy } \\
\text { resources }\end{array}$ & & & + & & + & + & & & 3 \\
\hline $\begin{array}{l}\text { Political security (freedom } \\
\text { from threats) }\end{array}$ & & & + & & + & & & + & 3 \\
\hline Environmental security & + & & & + & & + & & & 3 \\
\hline $\begin{array}{l}\text { Economically viable energy } \\
\text { generation }\end{array}$ & & + & & & & & & & 1 \\
\hline $\begin{array}{l}\text { Cultural security (freedom } \\
\text { from threats) }\end{array}$ & & & + & & & & & & 1 \\
\hline $\begin{array}{l}\text { Technological security } \\
\text { (freedom from threats) }\end{array}$ & & & & & & + & & & 1 \\
\hline $\begin{array}{l}\text { Security from terrorist attack } \\
\text { (freedom from threats) }\end{array}$ & & & & & & + & & & 1 \\
\hline Energy efficiency & & & & + & & & & & 1 \\
\hline $\begin{array}{l}\text { Power symmetry between } \\
\text { importers and consumers }\end{array}$ & & & & & + & & & & 1 \\
\hline
\end{tabular}

27 National Energy Independence Strategy, supra note 24, Art. 1.

${ }^{28}$ Ibid., Art. 19, Sec. 1.

${ }^{29}$ Ibid., Art. 1.

${ }^{30}$ Ibid., Art. 29. 
Table No. 3 shows that all the respondents stated that diversification of supply is an element of energy security. This shows the importance of this element in the perception of energy security. This is the core element of energy security perception and has not changed much since the first definition of energy security was presented by Winston Churchill in 1913 as: "safety and certainty in oil lie in variety and variety alone". The four elements of energy security that were mentioned the most were basically elements of the definition of concept of "energy independency" presented in the National Energy Independency Strategy.

However, self-sufficiency and acceptable price were mentioned by less than half of the respondents. This shows that these elements are not fully perceived as elements of energy security, and that definition is not yet entrenched in the minds of responsible decision makers. The element of the political security was mentioned three times, which shows that energy resources are perceived as tools of foreign policy and there is a need to have immunity to these tools.

The concept of energy security "spills" into other security sectors proposed by Barry Buzan. The interviewees mainly perceived energy security as it was defined by Daniel Yergin: "the objective of energy security is to assure adequate, reliable suppliers of energy at reasonable prices and in ways that do not jeopardize major national values and objectives" ${ }^{\prime 31}$. This definition has a broader context and is directly related to political elements. All the interviewees accentuated political elements of energy security. Respondent No. 3 argued that energy insecurity might lead that "one day we might be asked to change our coat of arms because if we don't, the price of electricity will be double".

Respondents mainly focused on electricity (mainly nuclear, and interconnections with Poland and Sweden) and natural gas when defining energy security, while supply of oil or domestic renewable resources were mentioned only episodically. This might be related to the fact that Lithuania has an oil terminal and can import oil from the global market, though it continues to import it from Russia, because pipeline Druzhba-2 has not been operational since 2006.

Renewable resources were mostly mentioned in the context of Visaginas NPP project, but only one interviewee from the Committee on Environmental Protection was eager to more broadly discuss the role of renewable resources. Episodically mentioned environmental elements show that responsible decision makers do not fully perceive them as elements of energy security. While International Energy Agency defines energy security as "the uninterrupted physical availability at a price

\footnotetext{
${ }^{31}$ Daniel Yergin, "Energy security in the 1990s," Foreign Affairs 67 (1) (1988): 111.
} 
which is affordable, while respecting environment concerns" ${ }^{\prime 32}$ and the EU Commission Communication underlines energy efficiency, environmental protection and sustainable development as elements of the concept of energy security. ${ }^{33}$ It is acknowledged by the Lithuanian experts that the main issue of Lithuanian energy security is low energy efficiency (especially in private sector due to not renovated blocks of flats built during soviet period), which is closely connected to environmental issues, as well as competitiveness of production and services, and lower imports of energy and energy resources.

The presented official documents underline the importance of a market approach to energy security. During the interviews only three respondents mentioned market approach in the context of acceptable prices for energy resources.

To sum up, energy security in most cases was perceived very primitively, basing responses on definitions presented a century ago, accentuating political aspects, while still mainly ignoring elements defining contemporary energy security, like environmental elements. When presenting definitions most of the respondents accentuated sources of energy that are most broadly discussed in the media electricity and natural gas. Analyzing relations between presented official documents and definitions of the respondents, the presented definitions were in most cases closer to the definition of energy security concept presented in the National Security Strategy rather National Energy Independency Strategy. Market principles were mentioned by only 3 respondents. The EU aspect in the definition was not presented, though National Security Strategy and National Energy Independency Strategy underlines this aspect. The presented "energy security" definitions have strong politicization, and great influence of political scientists as experts when presenting and defining issues of energy security to responsible decision makers.

\section{VIABILITY OF THE CONCEPT OF "ENERGY INDEPENDENCE"}

The newly presented strategy was titled the National Energy Independence Strategy. There were a lot of debates and interpretations concerning the term "energy independence". Introduction of this concept by the Government was not entirely successful. Only half of the interviewees agreed that concepts of "energy independence" and "energy security" have connections.

\footnotetext{
32 International Energy Agency, "Energy Security" // http://www.iea.org/subjectqueries/keyresult.asp?KEYWORD_ID=4103 (accessed May 7, 2012).

33 European Commission, "Energy 2020 A strategy for competitive, sustainable and secure energy," Communication from the Commission to the European Parliament, the Council, the European Economic and Social Committee and the Committee of the Regions, SEC(2010) 1346, (2010) // http://eurlex.europa.eu/LexUriServ/LexUriServ.do?uri=COM:2010:0639:FIN:EN:PDF (accessed May 7, 2012).
} 
Table 4. Assessments about connections between "energy security" concept and concept of "energy independence"

\begin{tabular}{|c|c|c|c|c|c|c|c|c|c|}
\hline $\begin{array}{l}\text { Does energy security have } \\
\text { connections with the concept } \\
\text { of "energy independence"? }\end{array}$ & 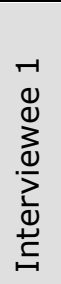 & 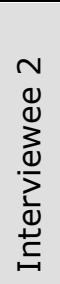 & 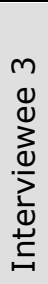 & 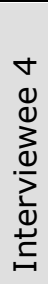 & 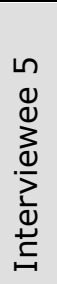 & 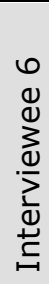 & 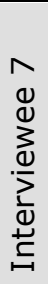 & 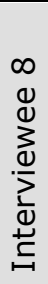 & 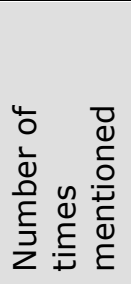 \\
\hline $\begin{array}{l}\text { Agree that "energy } \\
\text { independence" concept has } \\
\text { connections with energy } \\
\text { security }\end{array}$ & & - & + & & + & & + & + & 4 \\
\hline $\begin{array}{l}\text { Do not agree that "energy } \\
\text { independence" concept has } \\
\text { connections with energy } \\
\text { security }\end{array}$ & + & - & & + & & + & & & 3 \\
\hline
\end{tabular}

Though the concept of "energy independence", according to the interviewee from the Ministry of Energy, was created as a concept to promote a better understanding of the essence of "energy security", those two concepts are basically the same concept. Interviewees from the ministries argued that "energy security" and "energy independence" are similar categories, meaning: "the ability to choose freely the type of energy resources as well as suppliers". Similar responses were presented because of the coordination of positions between ministries when presenting them to the public so their argumentation would be essentially similar. Research shows that not all respondents indicate a connection between "energy security" and "energy independence" concepts. This concept was already criticized by arguing that term should not be used because it is not defined in any regulations. $^{34}$ One of the interviewees argued that the concept of "energy independence": "does not say anything, it is demagogic and propaganda, without any substance because interdependence and mutual dependence is what energy security defines". Respondent No. 6 argued that "energy independence" is "more a political category, because in contemporary world energy independence can be found extremely rarely and there even exist wishful energy dependency on certain suppliers or energy resources networks and grinds". A number of respondents argued that "energy independence" concept is basically connected to Lithuania's dependence on the energy systems and connections of former Soviet Union, and "energy independence" means independence from connections of former Soviet Union. In this context the "Constitutional Act of the Republic of Lithuania on the

\footnotetext{
34 Lietuvos laisvosios rinkos insitutas [Lithuanian Free Market Institute], "Pastabos dèl Nacionalinès energetinès nepriklausomybès strategijos projekto" ["Notes on the project of the National Energy Independence Strategy"], (September 30, 2010) // http://www.Irinka.It/index.php?act=main\&item_id=5860 (June 7, 2012).
} 
Non-alignment of the Republic of Lithuania to Post-soviet Eastern Unions" should be mentioned. According to it Lithuania cannot be a member of any unions' in the Post-soviet space "to never join in any form any new political, military, economic or other unions or commonwealths of states formed on the basis of the former USSR", while technical dependency on BRELL, though Lithuania has no agreements signed, could be argued as violation of Constitutional Act. To sum up, the concept of "energy independence", presented by the Ministry of Energy, is not absolutely viable and was not perceived identically by the respondents.

\section{EVALUATION OF ENERGY SECURITY LEVEL}

Research was also focusing on how responsible decision makers evaluate the energy security of the Republic of Lithuania, and on what they base their proposed evaluation. Since the evaluation of security is based on subjective perceptions, the question was given to the respondents: "How would you evaluate the level of Lithuania's energy security in the scale ranging from 1 to 10 , where 1 is absolute insecurity as you can imagine, and 10 is absolute security as you can imagine?"

Table 5. Evaluation of energy security level

\begin{tabular}{|c|c|c|c|c|c|c|c|c|c|}
\hline $\begin{array}{l}\text { How would you evaluate the } \\
\text { level of Lithuania's energy } \\
\text { security in the scale ranging } \\
\text { from } 1 \text { to } 10 \text {, where } 1 \text { is } \\
\text { absolute insecurity as you can } \\
\text { imagine, and } 10 \text { is absolute } \\
\text { security as you can imagine? }\end{array}$ & 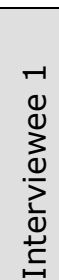 & 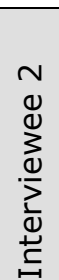 & 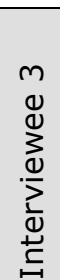 & 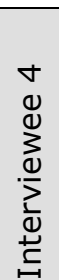 & 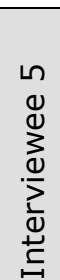 & 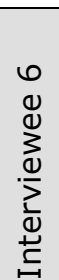 & 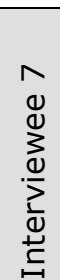 & 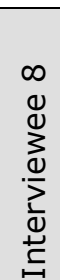 & $\begin{array}{l}0 \\
\bar{\sigma} \\
\frac{\pi}{0} \\
⿱ 亠 乂\end{array}$ \\
\hline Proposed evaluation & 4 & 4 & 3 & 5 & 5 & 4 & 2 & - & 3.86 \\
\hline
\end{tabular}

Most of respondents suggested that energy security of Lithuania is at level 4, and the average of suggested energy security level is at 3.86, while energy researchers claim that the level of energy security is at $5.15 .^{35}$ Interviewees had differently argued their suggested energy security level. Respondent No. 1 argued that Lithuania is extremely energy inefficient, and is tied to Russian supplied energy resources, comparing it to "drug addiction". Lithuania is more than two times less efficient than EU average (Lithuania's energy intensity - Gross inland consumption of energy divided by GDP, was $361.813 \mathrm{kgoe} / 1000$ Euros in year 2010 is compared to the EU average - $167.99 \mathrm{kgoe} / 1000$ Euros). ${ }^{36}$ Interviewee No. 2 referred only to the electricity sector, arguing that Lithuania can produce about 40 percent of

\footnotetext{
35 Juozas Augutis, Ričardas Krištolaitis, Dainius Genys, and Giedrius Česnakas, eds., Lietuvos energetinis saugumas. Metine apžvalga: 2011-2012 [Lithuanian Energy Security. Annual Review: 2011-2012] (Kaunas: Vytautas Magnus University, 2013), p. 17.

${ }^{36}$ Eurostat, "Energy intensity of the economy," (May 24, 2012) // http://appsso.eurostat.ec.europa.eu/nui/submitViewTableAction.do?dvsc=9 (accessed June 7, 2012).
} 
electricity self-sufficiently, so its energy security should be at level four. Interviewee No. 3 claimed that energy security is at level three because Lithuania depends only on Russian resources. Interviewee No. 4 argued that energy security can be divided into two types of issues: technical issues and prices volatility issues. Interviewee argued that in the technical sector Lithuania is quite secure and assessed its security at level 8, while price volatility was assessed at level 2 . Interviewee No. 6 argued that energy security at level 10 is impossible, and there is no need to seek of this kind of security, and it is better to discuss energy sufficiency. One interviewee stated that energy security of Lithuania is at level four, and that Lithuania still has domestic energy capacities as well as abilities to import and there are a lot of projects that should increase energy security. Another interviewee stated that the "situation is not as bad as sometimes it is presented in our [Lithuanian] media, but we have serious structural and systemic problems that we should deal with, but it is doable". Respondent No. 7 argued that it is better to evaluate level of vulnerability, and in this context respondent underlined price volatility and capabilities to secure supply.

The interviewees presented very different positions on how they evaluate energy security varying from energy intensity to energy vulnerability, but nevertheless their evaluations of energy security level were not very different, in the range from 5 to 2 , while level 4 was mentioned by most of the respondents. It could be assessed that basic perceptions on energy security level were approximate, but argumentation differed. The different argumentation is not consistent with responses on main challenges to energy security and definition of concept of "energy security", because in those cases the most of the respondents presented similar core elements while in this case there was no core element. The core element could be identified by interpretation of the answers, namely, that there is a lack of self-sufficiency.

\section{THE CONSTRUCTION OF ENERGY SECURITY PERCEPTION}

The next step of the research was to find how energy security perceptions were constructed and how responsible decision makers accumulate information to construct their perceptions on energy security leading to adoption of decisions. Interviewees were asked to identify what data and resources they used when presenting an answer on the energy security level.

Interviewee No. 1 claimed that his answer was based on various research: Lithuanian Energy Institute, nongovernmental organizations, Ministry of Economy (while it was responsible for energy policy - until the end of 2008), his own studies, 
conferences. Interviewee No. 2 stated that his evaluation was based on the research of Vytautas Magnus University and Lithuanian Energy Institute - "The Research on the Integrated Security Level Assessment Methodology Development for the Energy Security Analysis and Evaluation" (Lt. Energetinio saugumo analizès ir integruoto saugumo lygio vertinimo metodikos sukūrimas ir tyrimas), presented in January 2012. This interviewee also mentioned information provided by secret services. Interviewee No. 3 argued that his perception is based on the media, and information of from the secret services. Interviewee No. 4 argued that his perception is based on different materials, but the information from the Lithuanian Energy Institute is especially valuable. Interviewee No. 5 claimed that his perceptions are based on the information in the media, as well as the Ministry of Energy and Ministry of Economy and information of the district in which he was elected. Interviewee No. 6 argued that his perception is subjective, but based on empirical observations, information of official institutions, as well as on the previously mentioned research of Vytautas Magnus University and the Lithuanian Energy Institute. Interviewee No. 7 stated that his perceptions are based on official statistical data, different researches, as well as already mentioned research of Vytautas Magnus University and Lithuanian Energy Institute. Respondent No. 8 was not specific, claiming that energy security evaluations were based on statistical data and scientific research.

Most of the interviewees claimed that most important sources of information are research institutions and in particular Lithuanian Energy Institute and Vytautas Magnus University. It is obvious that the aforementioned research institutions have real influence on the decision-makers concerning energy security. However, they could mention only one particular research; though a number of interviewees claimed that there is much more research. These responses indicate that during the interviews interviewees want to present themselves as having more knowledge than they really do, because they cannot specify more researches or institutions. Interviewee No. 3 claimed that all the methods of energy security level assessment are known to him, but he was not able to mention particular method, research or institution.

It also can be assumed that information from the secret services has much greater impact on energy policy than it was mentioned in the interviews. Not all respondents wanted to reveal that they are working with sensitive information, but the ways that energy resources supply from Russia are securitized (how challenges and their negative effects are presented in the Strategies and in the interviews) illustrate that the assumption of the importance of secret services information is high. Reliance on information of secret services would explain connections between 
energy security perceptions and securitization of Russia in this context. Issues concerning energy security in the National Energy Independence Strategy overlap with the information presented in the Review of Activities of the State Security Department of the Republic of Lithuania of 2012. In the document it is claimed that "foreign states pay particular attention to the strategic energy projects that are developed in Lithuania. Lithuania's aspiration to buy cheaper energy resources and diversify supply in those countries is assessed as posing threats to their interests in the region".

Interviewees also claimed that when constructing perception on energy security level they use a lot of information from the media, statistic data and information provided by official institutions. The research shows lack of democratic approach towards energy security assessment. Only a single member of the Parliament mentioned that when constructing his perceptions he takes into account information of his electoral district.

Even interviewees claimed that their energy security perception is influenced by information in the mass media, when they identified energy security level of Lithuania, but when they were asked "Are your positions on energy security influenced by information in and mass media?", most of the respondents answered that their positions are not influenced. Most of the respondents claimed that public opinion and discussions in mass media force them to search for additional arguments in order to argue their position - to consolidate it. This position was presented by five interviewees, while only one claimed that his positions are not influenced by information in media, and one respondent claimed that his positions are somewhat influenced, but did not specify how. Interviewee No. 8 did not specify influence at all. Interviewees claimed that the information in media is usually politicized, and because of politicization they search for the arguments to present their positions that they perceive as objective.

Positions of the responsible decision makers are influenced by various interest groups and in the course of research it was identified which groups are most influential when adopting decisions. Interviewees were asked to identify groups with whom they consult and few groups, as examples, were mentioned (scientists in the field of energy, political scientists, economists and environmental scientists, NGO's, business groups). Interviewee No. 8 claimed that the institution he represents consults with wide list of experts, while responses of other interviewees were broader. The responses show that opinions, researches and views of the scientists working in the field of energy are the most influential, while governmental institutions and their members share second place with political scientists. 
It was unexpected that political scientists were mentioned as such an influential group. This indicates politicization of energy issues and politicized perceptions about energy security. The objectiveness of the positions of the political scientists is doubtful. There is a small number (four to five) of political scientists having doctoral degree that do their researches on energy issues, and at the same time work in the governmental institutions (Ministry of Foreign Affairs and the Energy Security Centre under the Ministry of Foreign Affairs) or do researches that are financed by governmental institutions. This dependency on governmental institutions might lead to deviations in their researches in order to justify institutional approach and their positions. Interviewee No. 4 also argued that political scientists cannot objectively present their assumptions, because political scientists represent certain schools and ideologies, and there is lack of leftist political scientists in Lithuania.

Table 6. Groups influencing responsible decision makers

\begin{tabular}{|c|c|c|c|c|c|c|c|c|c|}
\hline $\begin{array}{l}\text { With whom do you consult } \\
\text { while analyzing Lithuania's } \\
\text { energy (in)security, what } \\
\text { groups (scientists in the field } \\
\text { of energy, political scientists, } \\
\text { economists and } \\
\text { environmental scientists, } \\
\text { NGO's, business groups)? }\end{array}$ & 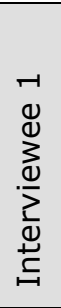 & 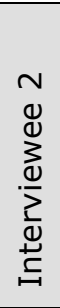 & 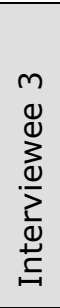 & 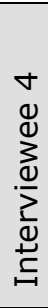 & 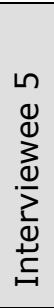 & 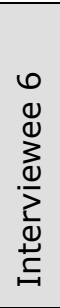 & 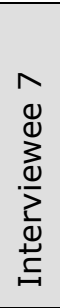 & 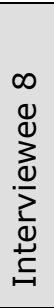 & 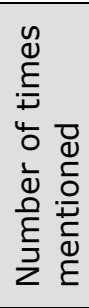 \\
\hline $\begin{array}{l}\text { Scientists in the field of } \\
\text { energy }\end{array}$ & + & + & & + & + & + & + & & 6 \\
\hline $\begin{array}{l}\text { Members of the Governmental } \\
\text { institutions }\end{array}$ & + & + & & & + & + & + & & 5 \\
\hline Political scientists & & + & & & + & + & + & & 5 \\
\hline Economists & & + & & + & & & + & & 3 \\
\hline Business groups & + & & & & & & + & & 2 \\
\hline Environmental NGO's & & + & & + & & & & & 2 \\
\hline Intelligence services & & + & + & & & & & & 2 \\
\hline $\begin{array}{l}\text { Associations of renewable } \\
\text { energy }\end{array}$ & + & & & & & & + & & 2 \\
\hline Members of the Parliament & + & & & & & & & & 1 \\
\hline EU institutions & + & & & & & & & & 1 \\
\hline International organizations & & & & & & + & & & 1 \\
\hline NATO institutions & & & & & & + & & & 1 \\
\hline Electorate & & & & & + & & & & 1 \\
\hline
\end{tabular}

Economists can be described as a less influential group, because only three interviewees claimed that they consult with economists or that positions of economists are important to them. Concerning development of energy security projects economists can be assessed as group with not enough influence. In the National Energy Independence Strategy it is claimed that "in order to reach energy independence public sector will have to invest 11 to 13 billion LTL (Lithuanian Litas) [3.2 - 3.8 billion $€$ ]" with additional investments from private sector of $3.2-4$ 
billion $€$, or more than 25 percent of total GDP of 2011. Other mentioned groups play a more marginal role in the decision making.

Public discussions and information in the media lead to consolidation of the positions of responsible decisions makers, while positions of the experts influence the formation of perceptions of responsible decisions makers. All the respondents claimed that their positions are mostly influenced by experts who present exact or specific data. Two respondents had not specified how they are influenced, while only one member of the Parliament mentioned that his positions are influenced by the electorate. Another interviewee claimed that there is an ongoing search for one absolutely reliable source, and an institution analyses all the opinions while looking at them in the systemic level, where each opinion could be used. Interviewees were not interested in what methodology or how expert research is prepared, and that they are interested only in results. This approach might lead to the manipulations of positions of responsible decision makers because they are not interested how results were discovered and on what based, as well as limited ability to check the results.

\section{CONTROVERSY SURROUNDING ENERGY NATIONALISM}

In the National Energy Strategy and the National Energy Independence Strategy most of the challenges to energy security and negative consequences of those challenges (already presented previously) are perceived as outcomes of Russia's energy nationalism. Actions of the Lithuanian government are presented as ways to increase immunity towards Russian energy nationalism. The ways to increase immunity force the expansion of state power and lead to an expansion in energy nationalism in the energy importing country. Kaveshnikov argues that "the Third [energy] Package increased state control over the energy sector" ${ }^{37}$.

The developing situation of the construction of nuclear power plant projects in Lithuania, Belarus and Russia allowed the opportunity to test whether energy nationalism is expressed by responsible decision makers when presenting assessments of NPP projects. Energy nationalism is indicated when it is presented by positive assumptions about the domestic energy projects perceiving them as safe, and negative assumptions about the foreign projects, perceiving them as unsafe. These assumptions are usually constructed denying positive / negative outcomes when ignoring technical, economic, environmental aspects - objective approach - best situation for all sides. The interviewees were given two questions: "How will Lithuanian energy security be affected by the selection of the strategic

37 Nikolay Kaveshnikov, "The issue of energy security in relations between Russia and the European Union," European Security Vol. 19, No. 4, (2010): 592. 
investor to the Visaginas NPP and signing of the initial treaty?" and "How will Lithuanian energy security be affected by NPP projects in Kaliningrad oblast and Belarus?"

Most of the interviewees perceived this question in a broader context as the question on their assessment of whole Visaginas NPP project. Interviewee No. 1 claimed that "first of all I must see the treaty and only after that I will be able to comment", while his perception about development of nuclear power was negative in general. Interviewee No. 2 claimed that signing of initial treaty allows hoping, that "one more step towards energy security will be made". Interviewee No. 3 claimed that he assesses development of NPP project together with Japanese company Hitachi, LTD. positively. Interviewee No. 4 claimed that "disregard of Russia had led to situation that today we will have two NPP's near Lithuania in Kaliningrad and Belarus, which is also Russian NPP, and we want build our own. If we have three NPP's will we feel more energy secure?" The interviewee is in favor of building one very powerful NPP in the region, and he negatively assesses implementation of the current Visaginas NPP project with participation of Japanese company. Interviewee No. 5 claimed that until now the question of NPP project is "up in the air", because "Government claims that it is responsible investor, powerful investor, there is nothing else to do, but to trust the Government". In general the interviewee assesses project positively. Interviewee No. 6 argued that successful negotiations with Hitachi indicate that Lithuanian energy system is perspective, and successful implementation of the project will increase Lithuanian energy independency. Interviewee No. 7 claimed that signing of the initial treaty "will increase possibility of realization of the project". Interviewee No. 8 claimed that "Because NPP is an important project to ensure energy security of Lithuania, the selection of the strategic investor is a crucial step to implement the project".

When assessing the impact of NPP projects in Belarus and Russia on Lithuanian energy security Interviewee No. 1 claimed that these projects negatively influence the energy security of Lithuania, because they will be developed on two main rivers flowing through territory of Lithuania, and it will be contaminated with radionuclides. At the same time interviewee argued that, although NPP in Visaginas will be constructed next on the border with Belarus, it will not contaminate Belarusian territory, because NPP will use water to cool reactor from the lake Druksiai. Interviewee No. 2 argued that in contrast to Lithuania, Belarus and Russia did not present environmental impact assessments of NPPs' regarding ESPOO convention, though those countries pledged to work according this convention. Interviewee No. 3 claimed that he does not trust Belarus or Russia, so "we are not sure that NPP in Belarus could not be used against our state politically. Belarus is 
unreliable in all political and economical aspects. Everything what is happening in unreliable state is dangerous".

Interviewee No. 4 claimed that in order to evaluate the impact of NPPs' in Belarus and Russia on Lithuania energy security a lot of difficult calculations are needed. The respondent also argued that NPP projects are overly politicized, because "if someone in Lithuania has position against Visaginas NPP he is an enemy of Lithuania, but if he is against NPPs' in Russia and Belarus he is our [Lithuanian] friend".

Interviewee No.5 argues that there is a big competition because "they [Belarus and Russia] do not want our NPP as well as we do not want their NPPs". The interviewee also claimed that there are no contacts between responsible decision makers of Lithuania and responsible decision makers in Belarus and Russia, as well as members of Parliament and Government. According to the interviewee, the responsible decision makers of Lithuania had not even attended the presentation organized by Rosatom to present Kaliningrad NPP project when it was organized and there is a lack of constructive approach on both sides. These statements are illustrated not only by this research, but also by the analysis of the governmental institutions in Lithuania, Belarus and positions of Russian corporation responsible for development of NPP projects. On the websites of the Ministry of Environment of Lithuania there are statements that NPPs' in Belarus and Kaliningrad are not safe because these projects are developed "not in compliance with international nuclear safety, radiation and environmental requirements, provisions of ESPOO convention on nuclear safety"38. The Ministry of the Natural Resources and Environmental Protection of the Republic of Belarus states that it wants to hold meeting with Lithuanian side in connection "with Lithuania's plans to use for its new nuclear power plant technology $\langle\ldots\rangle$ type of reactor, similar to that that was used in the Japanese nuclear power plant of Fukushima", and it is also stated that Belarus has additional issues concerning research done after assessments of impact on environment on the site of possible of Visaginas NPP. ${ }^{39}$ Russian state corporation Rosatom program director Sergei Boyarkin on June 4,

38 Lietuvos Respublikos Aplinkos ministerija [Ministry of Environment of the Republic of Lithuania], "Ženevoje ministras patvirtino griežta Lietuvos pozicija dèl planuojamu atominiu elektriniu Baltarusijoje ir Kaliningrado srityje" ["In Geneva Minister confirmed the strong position of Lithuania regarding the planned nuclear plants in Belarus and the Kaliningrad region"], (June 23, 2009) // http://www.am.It/VI/article.php3?article_id=10921 (accessed June 5, 2012).

39 Ministerstvo prirodnych resursov i ochrany okruzhayuschej sredy Respubliki Belorusia [Ministry of Natural Resources and Environmental Protection of the Republic of Belarus], "Press sluzhba soobschaet" ["Press release"] // http://www.minpriroda.by/ru/press_sl/p-alignjustify-strongministerstvo-prirodnyxresursov-i-oxrany-okruzhajuschej-sredy-respubliki-belarus-povtorno-obratilos-k-ministerstvuokruzhajuschej-sredy-litovskoj-respubliki-s-predlozheniem-provesti-konsultatsii-po-proektudvustoronnego-mezhvedomstvennogo-soglashenija-o-sobljudenii-konventsii-ob-otsenke-vozdejstvija-naokruzhajuschuju-sredu-v-transgranichnom-kontekste-konventsija-espo-a-takzhe-otvetit-na-nekotoryevoprosy-kasajuschiesja-planiruemogo-litvoj-stroitelstva-novoj-visaginskoj-aesstrongp_i_1131.html (accessed June 5, 2012). 
2012, at Atomexpo-2012 stated that "if Lithuania chooses this project [Hitachi] then Russia will immediately 'raise a lot of questions'; it [reactor] has never been used in the world and it is of 'Fukushima type'". ${ }^{40}$ Interviewee No. 6 assessed NPP projects in Belarus and Kaliningrad in three dimensions - ecological, economical, and national security. According to the interviewee NPP in Belarus will be built only 50 kilometers from Lithuanian capital, the site is chosen wrongly because of tectonic and geological aspects, and water to cool the reactor will be probably used from river Neris. Concerning economic issues, the interviewee argued that those projects will prevent development of Lithuanian economy. The interviewee also claimed that there are concerns for national security: "it is impossible to reject political motives behind those projects in order to prevent Lithuania from developing independent energy policy". When the interviewer stated that Belarus and Russia present the same issues concerning the Lithuanian NPP project, the interviewee argued that there is a need to defend Lithuanian project "in order not to be subordinated to the system or interests we do not trust".

Interviewee No. 7 agreed only to give his personal opinion arguing that projects will affect not energy, but national security: "there is a probability that those projects will be not safe and not transparent, and there are possibilities for radiation contamination". According to the interviewee project will not have negative consequences in the energy sector.

Interviewee No. 8 claimed that NPP projects developing in Belarus and Kaliningrad are not safe and they are being developed irresponsibly, because though all the necessary research and environmental impact assessments had not been done, works on the sites are still in process. In addition, these projects might have a enormously negative impact on Lithuanian national security in case of accident.

The perception on Visaginas NPP can be considered positive, while the perception of Belarusian and Russian NPP projects was negative, and the possibility of radiation contamination was mentioned as well as threats to national security. However, during the interviews not a single interviewee mentioned the possibility of radiation contamination from Visaginas NPP. The primitive model of thinking "what is ours is safe, what is others' is dangerous" dominates. One interviewee argued that if Belarus was "Switzerland" there would be no problems with their NPP. At the same time Lithuanian institutions suggest that regional LNG terminal in Riga (Latvia) could be not reliable, so Lithuania needs its own terminal. Similar issues

\footnotetext{
40 "Rossia obeschayet Vilniuskoj AES biurokratichesyj ad, Japonija nazyvaet proekt Hitachi polnostiu bezopasnym" ["Russia promises to Visaginas NPP bureaucratic hell, Hitachi, Japan calls the project is completely safe"], ru.15min./t (June 5, 2012) // http://www.15min.lt/ru/article/ekonomika/rossija-obeshchaet-visaginskoj-aes-bjurokraticheskij-adjaponija-nazyvaet-proekt-hitachi-polnostju-bezopasnym-505-224045 (accessed June 20, 2012).
} 
were raised concerning the Power Bridge between Sweden and the Baltic States, when implementation of the project was prolonged because Lithuania and Latvia were not able to decide to which country it should be built. Obviously the perception of Russia and Belarus as competitors is far-flung between responsible decision makers, while technological and environmental issues only strengthen this perception, while the perception about Latvia is similar, but not as radical. This shows the universality of energy nationalism and strives to expand state power and influence against other countries.

In this context the Nord Stream gas pipeline is an interesting case. The Nord Stream project was securitized not only by Poland's Defense Minister Radoslaw Sikorski in 2006, when he compared it to Molotov-Ribbentrop pact of 1939, but also in the National Energy Strategy of Lithuania as it claimed that: "the construction of a new gas pipeline to Europe under the Baltic Sea bypassing the territory of the Baltic States" is a challenge to Lithuanian energy security. During the research it was inquired "How will Lithuanian energy security be affected by the commissioning of Nord Stream pipeline?" Answers to this question indicate that the perceptions on already implemented projects change, or they remain the same. This allows for making assumptions if there are possibilities that perceptions about energy nationalism concerning NPP projects could decrease.

Interviewee No.1 argued that energy security of Lithuania is not affected, but he sees possibilities for the challenges in other security sectors. Russia could begin various military exercises in neutral waters justifying them as need to defend their property. Interviewee No. 2 argued that Nord Stream does not affect energy security, but it might if the pipeline leg to Kaliningrad will be built. Interviewee No. 3 claimed that "at first we thought it is a political agreement between Russia and Germany and we opposed it. $\langle\ldots>$ But now we see that this is a not very successful commercial project and nobody can explain to me what Russia gained form it". Interviewee No. 6 claimed that this was very intensively lobbied project between two powerful states, and small states like Lithuania were left aside. Interviewee No.6 claimed that there is no direct influence to Lithuania, but this might change if leg to Kaliningrad is built. Interviewee argued that pipeline creates environmental, judicial, as well as technological issues concerning safety and maintenance of pipeline. Interviewee No. 7 also argued that threats might occur from possible pipeline leg to Kaliningrad, because then Russia might disrupt gas supplies to Lithuania, and currently it cannot because there is only single pipeline to Kaliningrad via Lithuanian territory. In 2004 and 2010 supplies to Kaliningrad were affected because of gas conflicts between Russia and Belarus. The same issues were raised by interviewee No. 8 . 
The interviews showed that the Nord Stream pipeline is perceived as less of a challenge to Lithuanian energy security than it was in 2007, but the main issue was raised that the possible leg of pipeline to Kaliningrad might lead to natural gas supply disruptions in Lithuania. Interviewed responsible decision makers tend to position their negative assumptions about the projects based not on contemporary events, but about possible negative developments and threats in the future. This lead to the assumption that regardless of what projects are implemented in neighboring countries, especially in Belarus and Russia, projects will be associated with challenges to energy or national security.

\section{CONCLUSIONS}

Most of the securitized energy sector issues that are securitized by responsible decision makers are inevitably connected to Russia. Russia is the common denominator, whether it is perceived as threat or challenge to energy security. This kind of position dominates the perception of responsible decision makers; as well, the challenges to national energy security were named as outcomes of the mentioned perception. The perception that Russia creates challenges for Lithuanian energy security is obviously grounded in Lithuania's dependency on imports from Russia, as well as lack of interconnections with the EU member states. Nevertheless most of the interviewees argued that this possesses mostly political challenges as energy resources become tools to implement political objectives; additionally, it was accentuated in the Strategies to keep Lithuania in the sphere of Russian influence. However, issues like lack of market principles, high prices as well as environmental issues (low energy intensity) have only marginal significance.

This naturally leads responsible decision makers to put energy supply diversification as the core element of energy security concept and only then mention diversification of resources, self-sufficiency, acceptable price, political security and environmental security. All the elements, except for diversification of supplies, were mentioned by half or less of the interviewees. This allows for arguing that the perception of responsible decision makers about energy security is narrow and based on the element presented nearly century ago. Narrowness of energy security perceptions were represented by the focus on the issues on certain energy resources. Interviewees focused only on energy resources sectors that dominate public discourse - natural gas and electricity, while oil supply or renewable resources were left aside. 
The concept of "energy independence" is criticized and is not perceived as a valid concept by the interviewees-even the interviewee from the Ministry of Energy who presented this concept argued that this concept should be understood as independence from Russian supplies energy networks. Nevertheless the newest energy strategy is titled National Energy Independence Strategy.

Responsible decision makers assess Lithuanian energy security as pre-critical, averaging 3.86, while researchers assess level of energy security being at 5.15 . Assessments had very different argumentation taking into account infrastructure as well as political elements. The assessments were mostly based on the information provided by the scientists and researchers working in the field of energy studies, as well as members of the governmental institutions and political scientists. The last group is surprisingly influential, but this explains the politicization of energy issues as well political interpretation as Russia's actions in the field of energy. At the same time role of the economists is assessed as weak. Democratic elements of perception building on energy issues are very weak, because only single member of the parliament mentioned that opinions of his electoral influence his positions.

The information in media and public discourse affects responsible decision makers only one way - they only expand their confidence in the rightfulness of their position, because decision makers assume that oppositions to their position are politicized and wrong. The information in media forces them to look for additional arguments to defend their position.

Finally this kind of perception building and assessments about other opinions leads to energy nationalism and will to expand state power in order to achieve energy security. In the case of the NPP project in Lithuania, Belarus and Russia (Kaliningrad), most of the interviewees perceived Lithuanian NPP as more or less safe and a proper way to ensure energy security, while they argued that the NPP projects in Belarus and Russia are not safe and are opaque. At the same time the Ministry of the Natural Resources and Environmental Protection of the Republic of Belarus and Rosatom presented similar arguments against NPP project in Lithuania. The universalism of energy nationalism becomes completely valid in case of regional LND terminal in Latvia as well as in case of differing positions between Lithuania and Latvia on route of interconnection with Sweden. In general, energy nationalism is built not on an analysis of the existing situation, but on the perceptions that there will be possible issues in the future. This leads to the assumption that energy issues in Lithuania will remain securitized in the future because they expand state power. Perceptions about Russia will probably remain unchanged, as well as the actions of Russia in the energy sector, despite that the 
projects are supposed to ensure that "energy independence" will be successfully completed.

\section{BIBLIOGRAPHY}

1. Augutis, Juozas, Ričardas Krištolaitis, Dainius Genys, and Giedrius Česnakas, eds. Lietuvos energetinis saugumas. Metinè apžvalga: 2011-2012 [Lithuanian Energy Security. Annual Review: 2011 - 2012]. Kaunas: Vytautas Magnus University, 2013.

2. Belyi, Andrei. "New Dimensions of Energy Security of the Enlarging EU and their Impact on Relations with Russia." European Integration Vol.25 (4) (December 2003): 351-369.

3. Budrys, Kęstutis. "Bendradarbiavimo su Lenkija itaka Lietuvos energetiniam saugumui" ["Impact of the Cooperation with Poland on Lithuanian Energy Security"]. Lietuvos metinè strateginè apžvalga 2007 (2008): 213-240.

4. Buzan, Barry. Žmonès, valstybès ir baimè: tarptautinio saugumo studijos po Šaltojo karo [People, States and Fear: An Agenda for International Security studies in the Post Cold War Era]. Trans., ed. Gediminas Vitkus. Eugrimas, 1997.

5. Commission of the European Communities. "Green Paper: A European Strategy for Sustainable, Competitive and Secure Energy." Brussels, 8.3.2006, COM (2006) 105 final // http://europa.eu/documents/comm/green_papers/pdf/com2006_105_en.pdf (accessed May 7, 2012).

6. European Commission. "Energy 2020: A strategy for competitive, sustainable and secure energy." Communication from the Commission to the European Parliament, the Council, the European Economic and Social Committee and the Committee of the Regions. SEC(2010) 1346, (2010) // http://eurlex.europa.eu/LexUriServ/LexUriServ.do?uri=COM:2010:0639:FIN:EN:PDF (accessed May 7, 2012).

7. Eurostat. "Energy intensity of the economy." (May 24, 2012) // http://appsso.eurostat.ec.europa.eu/nui/submitViewTableAction.do?dvsc $=9$ (accessed June 7, 2012).

8. International Energy Agency. "Energy Security" // http://www.iea.org/subjectqueries/keyresult.asp?KEYWORD_ID =4103 (accessed May 7, 2012). 
9. Janeliūnas, Tomas, and Arūnas Molis. "Energy Security in Lithuania: Challanges and Perspectives." Lithuanian Political Science Yearbook 2005 (2006): 200-233.

10. Janeliūnas, Tomas. "Lithuanian energy strategy and its implications on regional cooperation": 190-222. In: Andris Sprūds and Toms Rostoks, eds. Energy: Pulling the Baltic Sea Region together or apart. Riga: Zinatne, 2009.

11. Kaveshnikov, Nikolay. "The issue of energy security in relations between Russia and the European Union." European Security Vol. 19, No. 4, (2010): 585-605.

12. Lietuvos laisvosios rinkos insitutas [Lithuanian Free Market Institute]. "Pastabos dèl Nacionalinès energetinès nepriklausomybès strategijos projekto" ["Notes on the project of the National Energy Independence Strategy"]. (September 30, 2010) //

http://www.Irinka.It/index.php?act=main\&item_id $=5860$

(accessed June 7, 2012).

13. Lietuvos Respublikos Aplinkos ministerija [Ministry of Environment of the Republic of Lithuania]. "Ženevoje ministras patvirtino griežtą Lietuvos pozicija dèl planuojamy atominiu elektriniu Baltarusijoje ir Kaliningrado srityje" ["In Geneva Minister confirmed the strong position of Lithuania regarding the planned nuclear plants in Belarus and the Kaliningrad region"]. (June 23, 2009) // http://www.am.It/VI/article.php3?article_id=10921 (accessed June 5, 2012).

14. Lietuvos statistikos departamentas [Lithuanian Department of Statistics]. "2010 m. Keitèsi šalies ir energijos sąnaudu struktūra" ["Changed National Fuel and Energy Structure in 2010"]. (June 15, 2011) // http://www.stat.gov.lt/lt/news/view/?id=9044 (accessed May 4, 2012).

15. Luft, Gal, and Anne Korin. "Realism and Idealism in the Energy Security Debate": 335-349. In: Gal Luft and Anne Korin, eds. Energy Security Challenges in the $21^{\text {st }}$ Century. A Reference Handbook. United States of America: ABC-CLIO, 2009.

16. McDonald, Matt. "Securitization and the Construction of Security." European Journal of International Relations Vol. 14(4) (2008): 351-369.

17. Ministerstvo prirodnych resursov i ochrany okruzhayuschej sredy Respubliki Belorusia [Ministry of Natural Resources and Environmental Protection of the Republic of Belarus]. "Press sluzhba soobschaet" ["Press release"]// http://www.minpriroda.by/ru/press_sl/p-alignjustify-strongministerstvoprirodnyx-resursov-i-oxrany-okruzhajuschej-sredy-respubliki-belaruspovtorno-obratilos-k-ministerstvu-okruzhajuschej-sredy-litovskoj-respubliki-s- 
predlozheniem-provesti-konsultatsii-po-proektu-dvustoronnego-

mezhvedomstvennogo-soglashenija-o-sobljudenii-konventsii-ob-otsenkevozdejstvija-na-okruzhajuschuju-sredu-v-transgranichnom-kontekstekonventsija-espo-a-takzhe-otvetit-na-nekotorye-voprosy-kasajuschiesjaplaniruemogo-litvoj-stroitelstva-novoj-visaginskoj-aesstrongp_i_1131.html (accessed June 5, 2012).

18. National Energy Strategy. Official Gazette, 2007, no. 11-430.

19. National Energy Independence Strategy. Official Gazette, 2012, no. 80-4149.

20. "Rossia obeschayet Vilniuskoj AES biurokratichesyj ad, Japonija nazyvaet proekt Hitachi polnostiu bezopasnym" ["Russia promises to Visaginas NPP bureaucratic hell, Hitachi, Japan calls the project is completely safe"]. ru.15min.lt (June 5, 2012) //

http://www.15min.It/ru/article/ekonomika/rossija-obeshchaet-visaginskojaes-bjurokraticheskij-ad-japonija-nazyvaet-proekt-hitachi-polnostjubezopasnym-505-224045 (accessed June 20, 2012).

21. Statistics Lithuania. "Energy Balance 2010." Vilnius (2011) // http://web.stat.gov.It/lt/catalog/pages_list/?id=1566 (accessed May 4, 2012).

22. Vitkus, Gediminas. "Russian Pipeline Diplomacy: A Lithuanian Response." Acta Slavica Iaponica 26 (2009): 25-46.

23. Waever, Ole. "New Schools' in Energy Security Theory and their Origins between Core and Periphery." Paper presented at the annual meeting of the International Studies Association. Montreal (March 17-20, 2004) // http://www.google.It/url?sa=t\&rct=j\&q=new\%20schools\%E2\%80\%99\%20in \%20energy\%20security\%20theory\%20and\%20their\%20origins\%20between $\% 20$ core $\% 20$ and $\% 20$ periphery\&source $=$ web\&cd $=1 \&$ cad $=$ rja\&ved $=0$ CCoQFjA A\&url=http\%3A\%2F\%2Fconstructivismointegracion.wikispaces.com $\% 2 F$ file $\%$ 2Fview\%2FAberystwyth\%2C\%2BParis\%2C\%2BCopenhagen\%2BNew\%2B'Sch ools'\%2Bin\%2BSecurity.doc\&ei=yC_MUb3mNcz3sgaP3YHAAg\&usg=AFQjCNEj DVArs3x1AxKpH85j9N4TQSdnxQ (accessed May 4, 2012).

24. Waever, Ole. "Securitization and Desecuritization": 46-86. In: Ronnie D. Lipschutz, ed. On Security. Columbia University Press, 1995.

25. Yergin, Daniel. "Energy security in the 1990s." Foreign Affairs 67 (1) (1988): 110-132. 